\title{
IZBOR KVALITETNE ŠUMSKE SADNICE POLJSKOG JASENA (Fraxinus angustifolia Vahl) ZA UMJETNU OBNOVU I POŠUMLJAVANJE
}

\section{Selecting high quality forest seedlings of narrow-leaved ash (Fraxinus angustifolia Vahl) for regeneration and reforestation purposes}

\author{
Damir DRVODELIĆ ${ }^{1}$, Milan ORŠANIĆ
}

\begin{abstract}
SAŽETAK:
U ovom stručnom članku detaljno su opisani svi čimbenici koji utječu na uzgoj kvalitetne šumske sadnice poljskog jasena za umjetnu obnovu i pošumljavanje. Do sada se pozornost nije poklanjala kvaliteti sadnica s obzirom na nove i potpuno promijenjene nepovoljne ekološke i biološke čimbenike koji se događaju sa sastojinama poljskog jasena u Hrvatskoj. Kvaliteta sadnica poljskog jasena određivala se isključivo jednim morfološkim čimbenikom, a to je najčešće visina izbojka što nije dobro. U radu su definirani pojmovi morfološke i fiziološke kvalitete sadnica. Opisane su metodologije za mjerenje morfoloških i fizioloških svojstava šumskih sadnica i njihov značaj na preživljenje, rast i prirast nakon sadnje na terenu. Morfološka svojstva su: visina izbojka, promjer stabljike, odnos visine izbojka i promjera stabljike, duljina pupa, volumen korijena i stabljike, težina sadnica, odnos volumena izbojka i korijena te boja, forma i oštećenja. Fiziološka svojstva su: otpornost na hladnoću, potencijal rasta korijena (PRK), dormantnost pupa i koncentracija hranjiva u lišću. Opisana su tri stresna čimbenika koja utječu na smanjenje kvalitete šumskih sadnica, preživljenje, rast i prirast na terenu, a to su: stres zbog vlage u biljci (PMS), stres zbog temperature i fizički stres (padanje, gnječenje, vibracije, površinsko oštećivanje i trganje korijena). Definirani su i svi ostali stresni čimbenici koji utječu na pad kvalitete šumske sadnice koji se događa u razdoblju od vađenja u rasadniku do sadnje na terenu. Razjašnjena je uloga pojedinog stresnog čimbenika na sadnice, kao i kumulativan utjecaj više stresnih čimbenika. U članku se govori o ispravnom rukovanju sadnicama od vađenja u rasadniku do pošumljavanja. Prikazane su novije patentirane mogućnosti zaštite sadnica od trenutka vađenja iz rasadnika ili kamiona-hladnjače do sadnje na terenu.
\end{abstract}

KLJUČNE RIJEČl: morfološka kvaliteta šumskih sadnica, fiziološka kvaliteta šumskih sadnica, stresni čimbenici kod šumskih sadnica, rukovanje sadnicama, zaštita sadnica

\section{UVOD}

\section{INTRODUCTION}

Na kvalitetu šumske sadnice utječu tri čimbenika: genetsko podrijetlo sjemena (kategorije šumskog reprodukcijskog materijala-ŠRM), klima rasadnika i uzgojni postupci u rasadničkoj tehnologiji. U obzir treba uzimati sva tri kri- terija kvalitete šumskih sadnica: genetski, morfološki i fiziološki. Genetski je određen provenijencijom sjemena i kategorijama ŠRM, morfološki kriteriji povezani su s vanjskim izgledom i stanjem sadnice (lako i brzo mjerljivi, jednostavnije metode rada i jeftina oprema), a fiziološki su povezani s unutarnjim, naoko nevidljivim stanjem biljke. Morfologija šumske sadnice je interakcija između nasljednih genetskih

\footnotetext{
1 Doc. dr. sc. Damir Drvodelić, Šumarski fakultet Sveučilišta u Zagrebu, Svetošimunska 25, 10000 Zagreb, email: ddrvodelic@inet.hr

${ }_{2}^{2}$ Prof. dr. sc. Milan Oršanić, Šumarski fakultet Sveučilišta u Zagrebu, Svetošimunska 25, 10000 Zagreb
} 
osobina, klime i uzgojnih postupaka u rasadniku. Prije svakog pošumljavanja, revirnik bi trebao dati upute tehnologu u rasadniku za proizvodnju šumskih sadnica prema mikroklimatskim i stanišnim čimbenicima (klima i tlo) koji su određeni na mjestu pošumljavanja. Već davno je u rasadničarstvu poznat pojam programirane šumske sadnice što se odnosi na rasadničku tehnologiju proizvodnje šumskog sadnog materijala prema unaprijed točno definiranim stanišnim čimbenicima (klima i tlo). Programirane sadnice nisu zaživjele u praksi zbog teže proizvodnje i više cijene, iako je s promjenom globalne klime došlo vrijeme da će se isključivo one trebati koristiti kod pošumljavanja ili umjetne obnove šumskih sastojina.

\section{ELEMENTI KVALITETE ŠUMSKIH SADNICA QUALITY ELEMENTS OF FOREST SEEDLINGS}

\section{Morfološka kvaliteta - 1. Morphological quality}

Morfologija se definira kao forma ili struktura nekog organizma. Iako morfološke procjene ne daju izravne informacije o trenutnom fiziološkom stanju, one se mogu smatrati fizičkim stanjem odgovora fiziološkog stanja sadnica na ekološke uvjete (Mexal i Landis 1990). Visina izbojka i promjer stabljike su uobičajene mjere kvalitete koje se koriste za rast i standarde klasiranja u šumskim rasadnicima. Postoji mnogo dodatnih morfoloških elemenata kvalitete koji se mogu dobro procijeniti. Morfološki elementi značajno se razlikuju od vrste, sjemenske zone i tipa sadnica. Niti jedan pojedinačni element kvalitete nije pokazao savršenu predikciju uspjeha sadnje, ali svaki od njih je povezan s ponašanjem sadnica na terenu. Morfološku kvalitetu šumskih sadnica istraživali su Oršanić i dr. (2007), Oršanić i dr. (2008a), Oršanić i dr. (2008b), Drvodelić i dr. (2012), Drvodelić i dr. (2013), Drvodelić i dr. (2016a), Crnković i dr. (2017) i još mnogi drugi.

\subsection{Visina izbojka - 1.1. Shoot height}

Visina izbojka definira se kao udaljenost od ožiljka kotiledona (supki) do baze vršnog pupa kod dormantnih sadnica ili vrha izbojka na sadnicama u vegetaciji. Visina korelira s brojem iglica na izbojku, to je dobra procjena fotosintetskog kapaciteta i transpiracijske površine. To sugerira na pozitivan odnos s kasnijim rastom, ali nepredvidiv odnos s preživljenjem, posebno na suhim terenima. Veće sadnice mogu imati konkurentsku prednost na terenima s ozbiljnom konkurencijom korova i mogu biti pokazatelj superiorne genetike. Jedanaest godišnji visinski rast sadnica duglazije $3+0$ visoko korelira s početnom visinom (Smith 1975). S druge strane, više sadnice s većom transpiracijskom površinom mogu biti lošije na suhim terenima, izuzetno visoke sadnice može biti teško za posaditi i one su nebalansirane (slab odnos izbojka prema korijenu). Visoke sadnice više su izložene djelovanju vjetra (Ritchie 1984). U vlastitim istraživanjima, sadnice poljskog jasena proizvedene u multikontejneru proizvođača AM-POLIM s 12 otvora i volumenom 1 otvora od $620 \mathrm{ml}$. u uvjetima hipoksije u razdoblju od 5.5.-15.7.2015. godine imale su u prosjeku $62 \mathrm{~mm}$ veći visinski i $1,81 \mathrm{~mm}$ debljinski prirast od zalijevanih sadnica, što je bilo statistički značajno. Poljski jasen je higrofilna vrsta i izrazito pozitivno reagira na navodnjavanje, a statistički značajne razlike utvrđene su osim u morfološkim i u nekim fiziološkim značajkama sadnica poput vodnog potencijala $(\Psi)$ i maksimalnog kvantnog prinosa fotosustava II $\left(\mathrm{F}_{\mathrm{v}} / \mathrm{F}_{\mathrm{m}}\right)$ koji je bio u optimalnom iznosu od 0,82. (Drvodelić i dr. 2016b).

\subsection{Promjer stabljike - 1.2. Stem diameter}

Promjer stabljike ili promjer vrata korijena definira se kao promjer glavne stabljike sadnice na ožiljku ili blizu ožiljka kotiledona. Promjer stabljike se često smatra najboljim pojedinačnim pokazateljem preživljenja i rasta na terenu (Thompson 1985). Promatrajući 14. nezavisnih elemenata kvalitete sadnica duglazije u rasadniku, promjer i težina korijena bila je u najvećoj korelaciji s prvih 5. godina visinskog rasta nakon sadnje (Omi i dr. 1986). Blake i dr. (1989) pišu o povećanju preživljenja s povećanjem promjera stabljike kod duglazije. Nakon 30. godina od sadnje vrste Pinus taeda L. utvrđeno je kako je prosječni volumen stabla u visokoj korelaciji s promjerom stabljike u vrijeme sadnje (South i dr. 1988). Sadnja sadnica duglazije $2 \mathrm{~mm}$ većeg početnog promjera dovela je nakon četiri godine do povećanja volumena stabljike od $35 \%$ i $43 \%$ s pokusima na dva različita lokaliteta (Rose i Ketchum 2003).

\subsection{Visina:promjer - 1.3. Height: diameter ratio}

Odnos između ukupne visine i promjera vrata korijena je koeficijent vitkosti ili vitkost (čvrstoća) sadnica. Visok odnos upućuje na relativno vitke sadnice dok niži odnos ukazuje na deblje sadnice. Sadnice nekih vrsta s velikim koeficijentom vitkosti osjetljivije su na oštećenja od vjetra, suše i mraza (Roller 1977).

\subsection{Duljina pupa - 1.4. Bud length}

Duljina pupa mjeri se od baze pupa do vrha pupa. Duljina pupa korelira s brojem iglica na sadnici kod mnogih vrsta i pokazatelj je dobrog inicijalnog rasta. Duljina pupa je korisna za predviđanje rasta izbojka (Kozlowski i dr. 1973).

\subsection{Volumen korijena i stabljike - 1.5. Root and stem volume}

Starije metode mjerenja volumena korijena i stabljike bile su potapanjem u vodu (Harrington i dr. 1994), dok se danas koriste suvremene, brze i precizne metode za mjerenje volumena i ostalih morfoloških varijabli opranog korijena uz pomoć skenera tipa Epson Expression 10000XL i softvera tipa WinRhizo Pro.V.. 2005 (Drvodelić i dr. 2013); 
Drvodelić i dr. 2015). Volumen korijena uključuje svu masu korijena ispod ožiljka od kotiledona, dok volumen izbojka uključuje svu masu izbojka iznad ožiljka kotiledona. Volumen korijena ne znači njegovu granatost, jer sadnice s puno finog korijenja mogu istisnuti isti volumen vode kao i sadnice s krupnim glavnim korijenom ili žilom srčanicom. Sadnice s većom masom korijena imaju veće korelacije ako se promatra promjer stabljike i preživljenje (Blake i dr. 1989). Sadnice duglazije i vrste Pinus ponderosa s većim volumenom korijena u vrijeme sadnje imale su značajno veći rast na terenu i preživljenje u odnosu na sadnice s malim volumenom korijena (Rose i dr. 1997). Jacobs i dr. (2005) navode kako su visina i promjer sadnica u drugoj godini bili veći kod sadnica tvrdih listača s većim početnim volumenom korijena. Analizirajući korijenske sustave jednogodišnjih sadnica pinije, uočeno je da su volumeni korijena sadnica iz kontejnera MP53/12 statistički značajno manji od volumena korijena sadnica iz ostalih kontejnera. Sadnice pinije proizvedene u kontejnerima većeg volumena $\mathrm{u}$ samo jednoj godini više su nego dvostruko akumulirale masu nadzemnog dijela, masu korijena, a time i ukupnu biomasu u odnosu na one proizvedene u kontejnerima manjeg volumena, što je više nego dobar pokazatelj utjecaja veličine kontejnera na morfološke značajke jednogodišnjih sadnica (Jelić i dr. 2014). Prema istom autoru volumen kontejnera u interakciji s pripremom tla bio je statistički vrlo značajan kod preživljena pinije. Drvodelić i dr. (2015) ističu kako je prilikom sadnje sadnica hrasta lužnjaka (Quercus robur L.) tretiranih s AgroHidroGelom utvrđena veća ukupna duljina korijena, veći prosječni promjer korijena, veći volumen korijena i više vrhova korijena u odnosu na kontrolne sadnice. Najveća duljina i volumen finog korijenja ( $<2 \mathrm{~mm}$ promjera) utvrđeni su kod sadnica s AgroHidroGelom i ektomikoriznim gljivama, a najmanji kod kontrolnih sadnica. Sadnice većeg volumena korijena imaju veći unos vode i hranjiva od sadnica manjeg volumena korijena, te je on jedan od ključnih čimbenika u izbjegavanju stresa u ranoj fazi nakon presadnje na teren, posebice tijekom ljetnog sušnog razdoblja (Tsakaldimi i dr. 2005). Volumen korijena i površina korijena sadnica u našem pokusu pokazuju signifikantne pozitivne korelacije s visinama sadnica i promjerima vrata korijena.

\subsection{Težine - 1.6. Weights}

Težina u svježem stanju je težina sadnice ili njezinih dijelova bez sušenja tj. odmah nakon uzimanja uzoraka. Težina $\mathrm{u}$ suhom stanju je težina sadnice ili njezinih dijelova nakon sušenja najmanje 48 sati na $68^{\circ} \mathrm{C}$. Težina se obično određuje na cijeloj sadnici ili korijenu, izbojku i lišću odvojeno. Iz razloga što sadržaj vode u tkivu može značajno varirati, težina u suhom stanju se češće mjeri i interpretira. Volumen izbojka i korijena u značajnoj je ovisnosti s masom izbojka i korijena u suhom stanju. Postoji jaka ovisnost između te- žine sadnica u suhom stanju i promjera stabljike (Ritchie 1984), što korelira s preživljenjem i rastom na terenu. Sadnice $s$ većom masom korijena imaju bolje preživljenje od onih s manjom masom korijena. Sadnice koje imaju mali promjer stabljike $(<3 \mathrm{~mm})$ imaju visoko preživljenje $(>70 \%)$ ukoliko imaju dobru masu korijena. Velike sadnice ( $>5 \mathrm{~mm}$ ) imaju dobro preživljenje čak s malom masom korijena. Rasadničari bi trebali proizvoditi sadnice s velikim promjerom vrata korijena, bez obzira na masu korijena ili uključiti ocjenjivanje korijena u proces klasiranja. Veći promjer vrata korijena može se postići s manjom gustoćom sjetve. O metodama za mjerenje težine korijena i stabljike u svježem i suhom stanju u svojim istraživanjima pišu Drvodelić i dr. (2015).

\subsection{Izbojak: korijen - 1.7. Shoot: root ratio}

Odnos volumena izbojka i korijena je pokazatelj balansa između transpiracijske površine $i$ apsorpcijske površine sadnica. Općenito, sadnice golog korijena imaju omjer izbojak:korijen 3:1 ili manje, a kvalitetne kontejnerske sadnice 2:1 ili manje. Kod nepovoljnog omjera suhe mase nadzemnog dijela i suhe mase korijenskog sustava sadnica za pretpostaviti je kako će one imati loš primitak na terenu, slabo preživljenje i inicijalni rast (Crnković i dr. 2017).

\subsection{Boja, oblik i oštećenja - 1.8. Colour, form, and damage}

Boja lišća sadnica je općeniti pokazatelj kvalitete sadnice i razlikuje se ovisno o vrsti i sezoni. Žuto, smeđe ili blijedozeleno lišće upućuje na nizak vigor i/ili sadržaj klorofila za razliku od tamnozelenog lišća. Postojanje višestrukih izbojaka, četkastog izbojka, deformacije korijena, snažnog postranog korijenja, fizičkih šteta ili bilo kojih vidljivih svojstva koja mogu utjecati na sadnice su također važni čimbenici za procjenu kvalitete.

\section{Fiziološka kvaliteta - 2. Physiological quality}

\subsection{Otpornost na hladnoću - 2.1. Cold hardiness}

Definira se kao temperaturni minimum kada će određeni postotak slučajno odabranih sadnica iz populacije preživjeti ili će dovesti do određene razine oštećenja (Ritchie 1984). Korijenje je manje otporno od izbojaka. $\mathrm{LT}_{50}$ (letalna temperatura za $50 \%$ populacije) obično se koristi za definiranje stupnja otpornosti na hladnoću. Promjene $\mathrm{u} \mathrm{LT}_{50}$ su snažno povezane s ciklusom dormantnosti sadnica i otpornosti na stres te su utjecane porijeklom sjemena, uzgojnim postupcima i klimom (Faulconer 1988; Burr 1990). Simpson (1990) piše kako $\mathrm{LT}_{50} \mathrm{u}$ momentu vađenja dobro korelira $\mathrm{s}$ preživljenjem u prvoj godini i rastom izbojka. Nakon vađenja sadnica rasadničari bi trebali zaštiti sadnice od niskih temperatura i očuvati im dormantnost. To se danas postiže čuvanjem u suvremenim hladnjačama na niskim pozitivnim temperaturama zraka i visokoj relativnoj zračnoj vlazi. 
Otpornost na hladnoću može se procijeniti testiranjem zamrzavanja cijele biljke u kojoj se ispituju oštećenja od zamrzavanja na pupovima, kambiju i lišću 6 dana nakon zamrzavanja (Glerum 1984; Tanaka i dr. 1997).

\subsection{Potencijal rasta korijena (PRK) - 2.2. Root growth potential (RGP)}

Sposobnost sadnice da započne stvaranje i/ili rast korijena u uvjetima koji pogoduju njegovom rastu (Ritchie 1985). Potencijal rasta korijena (PRK) obično se mjeri u kasnu zimu ili početkom proljeća ili sadnjom sadnica u posude ili hidroponske spremnike. Rast korijena se kvantificira nakon 3 tjedna. PRK je utjecan tipom sadnog materijala, vrstom, porijeklom sjemena i fiziologijom. Unatoč svojoj popularnosti, još nije sa sigurnošću utvrđen utjecaj PRK s uspjehom nakon sadnje. Podacima o potencijalu rasta korijena može se predvidjeti uspjeh sadnje ukoliko su sadnice mrtve ili kad je usvajanje vode ovisno o novom rastu. PRK predstavlja potencijal rasta novog korijena u pogodnim uvjetima. Taj potencijal može ili ne mora biti izražen kad se sadnice presađuju u vanjske uvjete. Rast korijena nakon presadnje rijetko započinje odmah, jer su temperature tla ispod optimalnih za njegov rast u odnosu na mjerenje PRK u kontroliranim uvjetima (Simpson i Ritchie 1997). O utjecaju potencijala rasta korijena na preživljavanje i rast sadnica crnog bora (Pinus nigra Arnold) pišu Bobinec Mikek, D. (2009) i Oršanić i dr. (2010). U istraživanjima Bobinec Mikek (2009) utvrđeno je kako je potencijal rasta korijena dobar pokazatelj potencijala sadnice za preživljavanje prilikom osnivanja novih šumskih kultura.

\subsection{Mirovanje pupa - 2.3. Bud dormancy}

Mjerenjem broja dana do pupanja u povoljnim uvjetima rasta je indeks stanja dormantnosti i otpornost na stres (Lavender 1985, Burr 1990). Brzina s kojom pupovi nastavljaju s rastom u proljeće je funkcija fiziološkog stanja pupa i ovisi o broju hladnih sati $\left(<5^{\circ} \mathrm{C}\right)$ kojim je sadnica izložena nakon razvoja pupa. Indeks mitoze (MI) je druga mjera dormantnosti pupa i za razliku od dana do pupanja, metoda je puno brža. Indeks mitoze se definira kao postotak stanica u procesu mitoze pri određenom vremenu. Owens i Molder (1973) pišu kako su pupovi duglazije dormantni kada je mitotska aktivnost u stanicama pupa na nuli.

\subsection{Koncentracija hranjiva u lišću - 2.4. Foliar nutrient concentration}

Stanje hranjiva u biljci ima ključnu ulogu u određivanju kvalitete sadnica i odgovarajućem uspjehu nakon sadnje. Stanje hranjiva u biljci može utjecati na čimbenike fiziologije sadnica koji su povezani s preživljenjem i rastom nakon presadnje na teren (Landis 1985). Veličina sadnica pozitivno korelira sa sadržajem dušika u lišću koji je izravno povezan s prihranom u rasadniku (van den Driessche
1980). Haase i dr. (2006) pišu kako je povećan sadržaj hranjiva u sadnici uslijed gnojidbe sa sporo otpuštajućim gnojivima imao značajan utjecaj na veličinu sadnica u vrijeme presadnje i nekoliko uzastopnih vegetacijskih razdoblja. Prejaka gnojidba utječe negativno na rast korijena. Ako se stavlja gnojivo u sadnu jamu onda ga treba staviti ispod korijenskog busena, a ne sa strane. Za rast i razvoj korijena puno je važniji kisik i voda nego biljna hranjiva. Sjeme poljskog jasena može se prije sjetve mikorizirati s endomikoriznim micelijima gljiva što je najjeftinija metoda za praksu. Sadnice se uz pomoć brizgaljke tipa Marolex mogu mikorizirati kad su veličine oko $15-20 \mathrm{~cm}$. To je skuplja metoda. U istraživanjima Drvodelića (2017) s devet različitih tretmana uzgoja kontejnerskih sadnica $\left(620 \mathrm{~cm}^{3}\right)$ poljskog jasena, najveće visine pri kraju prve vegetacije postignute su u slučaju primjene vodnog absorbenta (AgroHidroGel), ektomikorize, normalne gnojidbe (4 g osmocota/ 11 supstrata) i redovitog zalijevanja (36 puta u vegetaciji, ukupno 2,57 1 vode po sadnici). Dicksonov indeks kvalitete (DQI) uzima u obzir morfološke značajke sadnica a računa se prema formuli:

$$
D Q I=\frac{U B(g)}{\frac{H(\mathrm{~cm})}{P V K(\mathrm{~mm})}+\frac{M S(g)}{M K(g)}}
$$

Gdje je:

$\mathrm{UB}=$ ukupna biomasa biljke u suhom stanju

$\mathrm{H} \quad=$ visina nadzemnog dijela biljke

$\mathrm{PVK}=$ promjer vrata korijena

MS = masa stabljike u suhom stanju

$\mathrm{MK}=$ masa korijena u suhom stanju

Što je DQI veći sadnice su bolje morfološke kvalitete. Najveći DQI u iznosu od 0,84. utvrđen je kod kontejnerskih sadnica poljskog jasena tretiranih vodnim absorbentom, normalnom gnojidbom i zalijevanjem svaki drugi put. Takve kontejnerske sadnice imaju najbolju kvalitetu s obzirom na morfološke značajke. Najmanji Dicksonov indeks kvalitete (DQI) u iznosu od 0,63.utvrđen je kod sadnica tretiranih vodnim absorbentom, uz gnojidbu od 50\% od normalne i redovito zalijevanje. Primjena ektomikoriznih micelija u svim tretmanima povećala je visinski rast sadnica. Dobra mikorizna simbioza nastupa samo u uvjetima kada tlo ili supstrat nisu suviše vlažni i kada se nije obavljala prekomjerna prihrana, posebno dušičnim gnojivima. Mikoriza je bolja u slučaju prihrane $\mathrm{s} \mathrm{NO}_{3}{ }^{-}$oblikom dušika za razliku od $\mathrm{NH}_{4}{ }^{+}$Kod proizvodnje kvalitetnih mikoriziranih biljaka u rasadniku treba voditi brigu o odgovarajućoj prihrani dušikom. Kod proizvodnje šumskih sadnica gologa korijena, tla ne bi smjela imati manje od 5\% humusa. Ako je taj postotak puno niži (a obično je), potrebno je kod pripreme tla za sjetvu ili presadnju dodati mikrohranjiva, ko- 
risne mikroorganizme i huminske kiseline, čime se izravno povećava organska tvar i mikrobiološka aktivnost tla. Treba strogo paziti na koncentraciju huminskih kiselina, što se postiže otapanjem u vodi. Huminske kiseline djeluju pozitivno na rast biljke, ali u strogo ograničenim koncentracijama. Preniske i previsoke koncentracije nisu stimulativne za rast biljke. Dušik i kalij biljke brzo apsorbiraju i potreba za tim elementima postepeno pada prema kraju vegetacijskog razdoblja za razliku od fosfora kojega biljke trebaju dvokratno (maksimalna apsorpcija je u lipnju i rujnu). Fosfor je slabo mobilan u tlu i u biljci. Kao pomoć u vezivanju fosfora pomaže mikoriza. $U$ rasadniku su biljke u sredini reda na gredicama u većoj kompeticiji, i zbog toga mogu usvojiti manje dušika od onih na kraju reda blizu kolotraga traktora. Ukoliko nakon rano jesenske sadnje u proljeće nastupi kraće ili dulje razdoblje s poplavama, dolazi do ugibanja prirodne mikorize u tlu zbog nedostatka kisika. $\mathrm{Na}$ terenima s proljetnim poplavama nužno je obaviti mikorizaciju sadnica nakon povlačenja poplavnih voda. $U$ rasadnicima koji proizvode sadnice poljskog jasena treba folijarnim putem pred kraj vegetacijskog razdoblja dodati kalijeva i fosforna gnojiva. U tom trenutku svi ugljikohidrati i hormoni putuju u pupove i korijen. Fertirigacija s fosfornim gnojivima značajno bi potaknula rast korijenskog sustava dok je kalij zaslužan za otpornost biljke prema visokim i niskim temperaturama. Otpornost sadnica prema visokim temperaturama može se popraviti zalijevanjem korijena ekstraktom biljke Yucca koja pojačava otpornost sadnice prema suši i sušnom stresu. Kod velikih sadnica u rastilištu rasadnika $(1+1,1+2,2+2 \mathrm{i}$ sl.), potrebno je u sustav navodnjavanja dodati lignin koji je dobar za rast i čvrstoću drva, što je važno u situacijama kada se oko sadnica poljskog jasena nakon povlačenja poplavnih voda pojavi ledena kora, a nema tulijevih cijevi kao nosača ledene kore. Takve sadnice bit će otpornije na savijanja zbog pritiska leda. Voditelji rasadnika trebaju obvezno pratiti fenologiju sadnica poljskog jasena.

\section{Stresni čimbenici kod šumskih sadnica - 3. Stress factors in forest seedlings}

Stresni čimbenici za šumsku sadnicu su: ekstremne temperature, isušivanje, mehaničke ozljede i smanjivanje zalihe hranjiva. To je razdoblje najvećeg financijskog rizika u poslovanju. Stres sadnica obično nije vidljiv jednostavnim promatranjem. Bez daljnjeg testiranja, često je teško odrediti je li stres utjecao na kvalitetu sadnica. To može dovesti do toga da se mrtve ili suhe sadnice sade na teren, što je gubitak vremena i novca. Sadnice su žive i kvarljive te mogu doživjeti stres tijekom uzgoja, vađenja, pakiranja, klasiranja, rukovanja, orezivanja, čuvanja, transporta i presadnje na teren. Zadatak rasadničara i osoba koje se bave pošumljavanjem je uzgoj sadnice visoke kvalitete u trenutku kad izađu iz rasadnika. Ekstremni ekološki čimbenici, ali i loše rukovanje sadnicama mogu dovesti do smanjenja njihove kvalitete. Tri primarne vrste stresa koji utječu na kvalitetu sadnica su vlaga, temperatura i fizički stres. Kumulativni utjecaj tih stresova može biti veći od sume pojedinačnog stresa. $S$ povećanjem stresa, fiziološke funkcije su narušene i energija sadnica troši se na ponovo uspostavljanje normalne funkcije. Kao rezultat preživljenje i rast mogu se značajno smanjiti. Ovi učinci se dodatno pogoršavaju kada se sadnice sade u teškim uvjetima.

\subsection{Vodni stres u biljci - 3.1. Plant moisture stress (PMS)}

Mjerenjem vodnog stresa u biljci (PMS) utvrđuje se vodni potencijal $(\Psi)$ koji predstavlja interakciju između opskrbe, potrebe i regulacije biljke za vodom. PMS se često koristi za određivanja režima navodnjavanja i prati vodni stres tijekom vađenja i pakiranja sadnica (Lopushinsky 1990). Za mjerenje vodnog stresa u biljci najčešće se koristi prijenosna tlačna komora (Cleary i Zaerr 1980). Na stres zbog vlage u biljci može utjecati doba dana, vrsta, dob sadnica, stupanj dormantnosti i otpornost na stres i okoliš. Umjereni vodni deficit dovodi do zatvaranja puči, smanjenja fotosinteze i rasta. Veliki vodni deficit može dovesti do trajnog oštećenja fotosintetskog sustava kao i drugih fizioloških procesa u biljci, što će utjecati na rast ili preživljenje. Utjecaj navodnjavanja u rasadnicima do sada se uglavnom istraživao kroz mjerenje i utvrđivanje osnovnih elemenata kvalitete sadnica poput visine, promjera vrata korijena i preživljenja, dok se bolja slika može dobiti isključivo detaljnom analizom nadzemnog i podzemnog dijela sadnica. Navodnjavanje utječe na fiziologiju sadnica. Mjerenjem vodnog stresa u biljci je brza, mobilna, relativno jeftina i nedestruktivna metoda i trebala bi se provoditi u svim rasadnicima za utvrđivanje režima navodnjavanja. Prema Drvodeliću i dr. (2016c), kontejnerske sadnice poljskog jasena (Fraxinus angustifolia Vahl) iz tretiranja suše odmah su propale. Sadnice saturirane vodom do korjenovog vrata imale su veći visinski i debljinski rast, niski vodni potencijal i manji fiziološki šok od sadnica koje su normalno zalijevane. Zaključak istraživanja je kako sadnicama poljskog jasena kao higrofitnoj vrsti drveća ne odgovaraju sušni uvjeti bez navodnjavanja. Kod sadnica saturiranih vodom u trajanju od 72 dana utvrđen je bolji morfološko-fiziološko status za razliku od normalno zalijevanih sadnica.

\subsection{Vodni stres - 3.2. Moisture stress}

Od svih stresova, stres zbog vlage može biti najštetniji. Gubitak vode tijekom rukovanja i sadnje mogu imati velik utjecaj na preživljenje i rast sadnica. Vodni potencijal biljke utječe na mnoge osnovne fiziološke procese, ovi utjecaji mogu biti vidljivi nekoliko godina nakon presadnje. Korijen biljke je posebno osjetljiv na isušivanje, jer za razliku od lišća i iglica nema voštanih prevlaka ili puči koji bi ga štitili 
od gubitka vode. Jednom kad se fino korijenje osuši, ono je vjerojatno već mrtvo. U odnosu na korijen sadnica gologa korijena, kod kontejnerskih sadnica korijen je zaštićen od stresa uzrokovanog nedostatkom vlage jer je obložen supstratom. Ukoliko se supstrat u kontejneru presuši, štete od isušivanja mogu biti velike. Jednom kad se korijenje osuši, ponovo vlaženje je neučinkovito, čak kad se vodni potencijal stabljike oporavi (Balneaves i Menzies 1988). Dormantne sadnice četinjača su osjetljivije na oštećenja zbog izloženosti korijena u odnosu na sadnice listača. U situacijama kad nakon jesenske ili proljetne sadnje sadnica dođu poplave na takvim terenima treba saditi školovane sadnice koje će većim dijelom biti iznad razine poplavnih voda. Poznato je kako pomladak hrasta lužnjaka u vegetaciji može preživjeti u vodi 8-10 dana, a pomladak vrbe 14 dana. Prema istraživanjima Drvodelića (2017), sjeme poljskog jasena koje nije proklijalo nakon stavljanja kontejnera u vodu nije nastavilo s klijanjem u vodi, što znači da sjeme ne klija u uvjetima niskog parcijalnog pritiska kisika. Potrebe za energijom tijekom klijanja ova vrsta ne može zadovoljiti zahvaljujući aktivaciji enzima vrenja. U slučaju sadnica poljskog jasna potopljenog u vodi utvrđeni su sljedeći rezultati:

Početak odumiranja: 11.-46. dan (prosjek 30 dana).

Kraj odumiranja:11.-46. dan (prosjek 33 dana).

Trajanje odumiranja: 3.-28. dana (prosjek 5,5 dana).

Početak, kraj i trajanje odumiranja ovisno je o genotipu. Nekroza se širila od najmlađih listova prema starijim. Nije utvrđena značajna korelacija između visina sadnica $(\mathrm{mm})$ i kraja odumiranja (dani) (Drvodelić 2017). U promatranom razdoblju (2004 - 2006 i 2010 - 2013) u G. J. Lonja, šumarija Sunja, poplave su iznosile od 24. do 198. dana, a prosječno trajanje poplava za 7. godina mjerenja iznosilo je 97. dana. Inače, na močvarnim terenima, kao i onima koji su izloženi periodičnim poplavama ili su jako zakorovljeni, za pošu- mljavanje treba koristiti starije školovane sadnice ili presađenice. Takvim sadnicama ne smeta visina poplava a vršni pup im je oslobođen od korova,a u sebi imaju više ugljikohidrata od onih mlađih i nepresađenih, pa je i preživljenje veće uz nepovoljne ekološke čimbenike koji se događaju u području rasprostranjenja šuma poljskog jasena u kontinentalnom dijelu Republike Hrvatske (manjak vode u ljetnim mjesecima, prevelika zasićenost tla vodom u proljeće i dr.).

\subsection{Temperaturni stres - 3.3. Temperature stress}

Stres zbog temperature također utječe na kvalitetu sadnica. Preživljenje i rast mogu biti smanjeni nakon izlaganja visokim ili niskim temperaturama. Razina osjetljivosti ovisi o stanju sadnica i fenologiji. Slično je i sa sadnicama koje nisu dovoljno odrvenjele pa stradaju od smrzavanja. Genotip i vrsta također utječu na stupanj ugroženosti od temperaturnog stresa (Haase, D. L., 2007).

\subsection{Fizički stres - 3.4. Physical stress}

Tijekom procesa uzgoja u rasadniku, kao i prilikom sadnje na terenu, kod sadnica se događa njihovo fizičko o štećenje što podrazumijeva padanje, gnječenje, vibracije, površinsko oštećivanje i trganje korijena. Često se vreće i kutije sa sadnicama bacaju s kamiona, što je veći pad, veće su štete. Istraživanja su pokazala kako padanje sadnica može smanjiti elektrolitsku provodljivost finog korijenja, smanjiti potencijal rasta korijena, smanjiti visinski rast i povećati mortalitet (Tabbush, 1986, Sharpe i dr. 1990, McKay i dr. 1993).

\section{Kvaliteta sadnog materijala nakon vađenja - 4. Quality of planting material after lifting}

Morfologija sadnica je kombinacija triju čimbenika: porijekla sjemena, lokacije rasadnika i uzgojnih mjera. Ekonomska vrijednost sadnica je najveća prije transporta $(\mathrm{Pa}-$

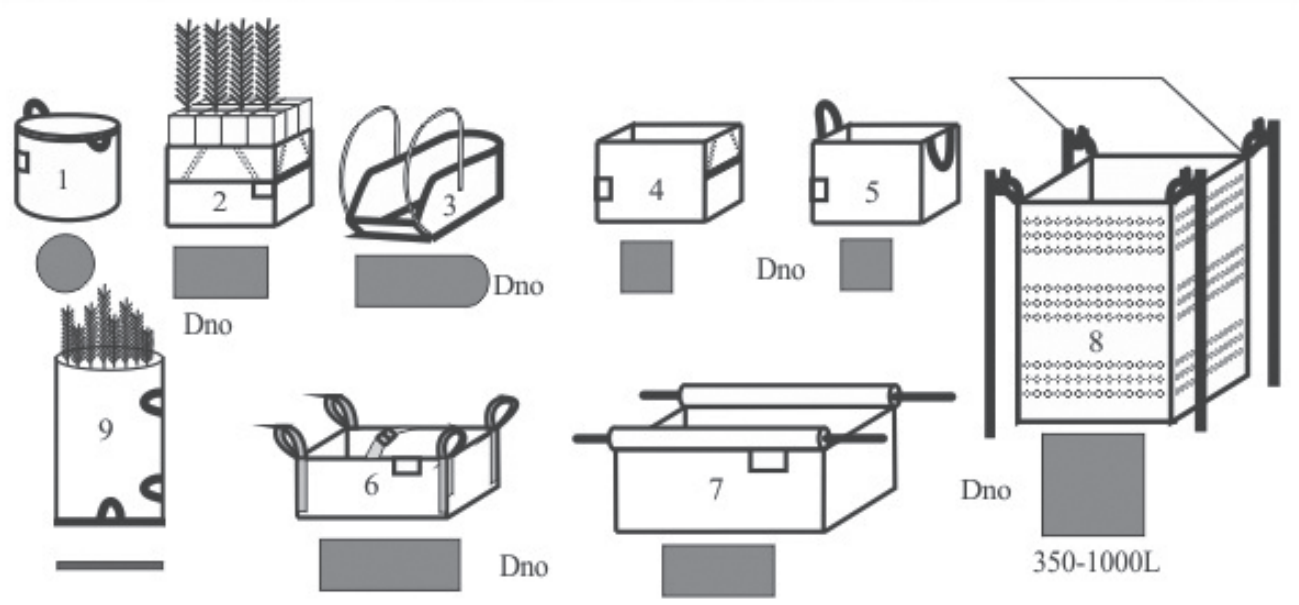

Slika 1. Shematski prikazi različitih oblika kontejnera i dna kontejnera za transport sadnica kod pošumljavanja i umjetne obnove sastojina sadnjom sadnica.

Figure 1. Schematic representation of different types of containers and container bottoms for seeedling transportation used in reforestation and artificial regeneration of stands by planting seedlings. 


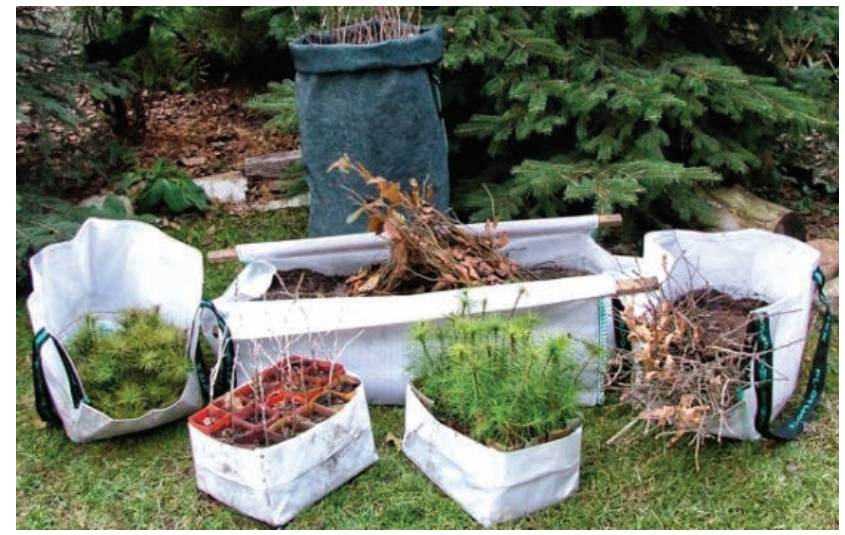

Slika 2. Različiti oblici kontejnera za transport sadnica kod pošumljavanja i umjetne obnove sastojina sadnjom sadnica.

Figure 2. Different forms of containers for transportation of seedlings for reforestation and artificial regeneration of stands by planting seedlings.

terson i dr. 2001). Nakon vađenja kvaliteta sadnica se ne može povećati već se ponekad smanjuje. Prema Adams i Paterson (2004), nepravilno rukovanje sadnicama važnije je od alata s kojim se sadi na terenu. Kvaliteta sadnica predstavlja lanac gdje svaka karika čini jedan segment u u rukovanju sadnicama od trenutka vađenja do sadnje na terenu. Značajniji je kumulativni učinak više stresnih čimbenika nego suma jednog stresora (McKay 1997). Šumska sadnica prolazi kroz različite stresne čimbenike, kronološki kako slijedi: vađenje (čuvanje) - rukovanje - transport-čuvanje na mjestu sadnje-sadnja. Ukupna kvaliteta sadnice se izražava kao kvaliteta najslabije karike u lancu. $S$ povećanjem stresa biljka preusmjerava energiju za rast na saniranje ozljeda. Poljski jasen pripada u skupinu higrofilnih vrsta drveća pa je razumljivo kako je korijenski sustav nakon vađenja sklon brzom isušivanju korjenovih dlačica koje su od odlučujućg značaja za preživljenje sadnica nakon presadnje. Zbog neodgovarajućeg postupanja šumskim sadnicama od trenutka vađenja u rasadniku do sadnje na terenu sadnice propadaju. Sadnice treba vaditi u rasadnicima po povoljnom vremenu što znači bez vjetra i jake sun-

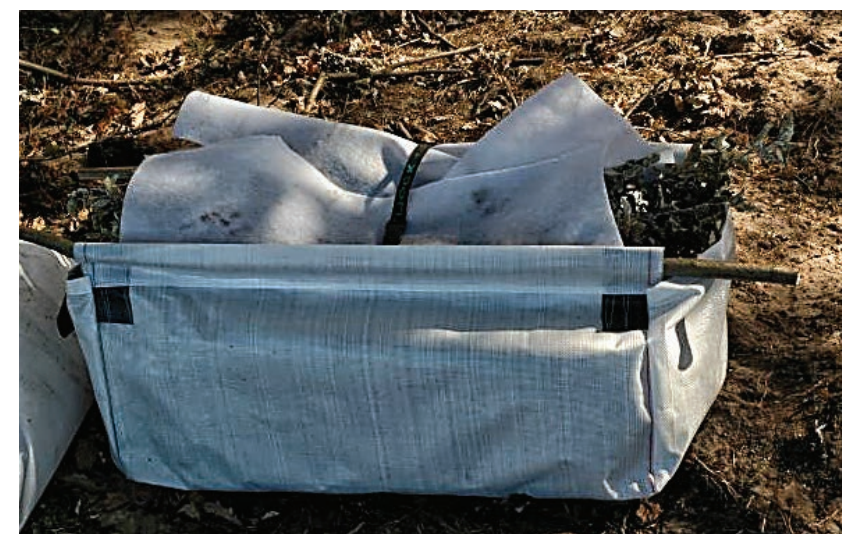

Slika 3. Kontejner za transport sadnica koji nose četiri osobe Figure 3. Container for seedling transportcarried by four persons čeve radijacije. Korijenski sustav sadnica poljskog jasena, ali i ostalih vrsta mora biti prikladno zaštićen do trenutka presadnje na terenu. Najbolje je ako sadnice iz rasadnika odmah idu na teren u kamionima s hladnjačom (niske temperature i visoka vlažnost zraka). U svijetu se koriste posebne vreće i kontejneri za transport i zaštitu sadnica od trenutka vađenja iz rasadnika ili kamiona-hladnjače do sadnje na terenu. U takvim vrećama ili kontejnerima, korijenski sustav sadnica je zaštićen od vjetra i sunčeve radijacije. U zadnje vrijeme dosta se proizvode kontejneri za zaštitu sadnica tijekom rukovanja (slika 1.).

Na slici 2. prikazani su različiti oblici kontejnera za transport sadnica kod pošumljavanja i umjetne obnove sastojina sadnjom sadnica. Takvi kontejneri čuvaju lišće i izbojke od nagle transpiracije, a korijenski sustav od isušivanja zbog vjetra.

Postoje i veliki kontejneri (slika 3.) za transport sadnica koji nose četiri osobe, a mogu imati primjernu upravo kod sadnica poljskog jasena koji je brzo rastuća vrsta u mladosti.

$\mathrm{Na}$ terenu je važno posaditi žive i morfološki prilagođene sadnice stanišnim prilikama te one sadnice koje su od trenutka vađenja do sadnje na terenu doživjele što manje stresnih čimbenika koji umanjuju njezine kvalitete. U takvim situacijama za očekivati je dobar uspjeh nakon sadnje ( 80 i više \%) i manje troškove na popunjavanju.

\section{LITERATURA REFERENCES}

- Adams, J. C., W. B. Patterson, 2004: Comparison ofplanting bar and hoedad planted seedlings for survivaland growth in a controlled environment. In: Connor KF,editor Proceedings of the 12th Biennial SouthernSilvicultural Research Conference. Asheville (NC):USDA-Forest Service, Southern Research Station.General Technical Report GTR SRS-71: 423.-424.

- Balneaves, J. M., Menzies, M. I. 1988: Lifting and handling procedures at Edendale Nursery-effects on survival and growth of 1/0 Pinus radiata seedlings. New Zealand Journal of Forestry Science, 18:132.-134.

- Blake, J. I., L. D. Teeter, D. B. South, 1989: Analysis of the economic benefits from increasing uniformity in Douglas-fir nursery stock. In: Mason, W. L., J. D. Deans, and S. Thompson, editors. Producing uniform conifer planting stock. Forestry Supplement 62:251.-262.

- Bobinec Mikek, D., 2009: Utjecaj potencijala rasta korijena sadnica crnog bora (Pinus nigra F. J. Arnold) na njihovo preživljavanje. Magistarski rad. Sveučilište u Zagrebu, Šumarski fakultet. 180. str.

- Burr, K. E., 1990: The target seedling concepts: bud dormancy and cold hardiness. In: R. Rose, S. J. Campbell, T. D. Landis, editors. Target seedling symposium: combined proceedings of the western forest nursery associations; 1990 August 13-17; Roseburg, OR. Fort Collins (CO): USDA Forest Service, Rocky Mountain Forest and Range Experiment Station. General Technical Report RM-200: 79.-90. str. 
- Cleary, B. D., J. B. Zaerr, 1980: Pressure chamber techniques for monitoring and evaluating seedling water status. New Zealand Journal of Forest Science, 10:133.-141.

- Crnković, S., D. Drvodelić, S. Perić, 2017: Morfološke značajke kontejnerskih sadnica hrasta lužnjaka (Quercus robur L.) iz sjemenske regije gornja Posavina i Pokuplje (1.2.3.). Šumarski list, 9-10: 451.-458.

- Drvodelić, D., M. Oršanić, Z. Zeman 2012: Uspjeh pošumljavanja jednogodišnjim $(1+0)$ i školovanim $(1+1)$ sadnicama divlje kruške (Pyrus pyraster Burgsd.). Šumarski List, 7-8: 355.-366.

- Drvodelić, D., M. Oršanić, S. Perić, M. Tijardović, 2013: Utjecaj navodnjavanja i mikroreljefa u rasadniku na morfološke značajke šumskih sadnica hrasta lužnjaka (Quercus robur L.) i kitnjaka (Quercus petraea L.). Šumarski list, 9-10: 447.-459.

- Drvodelić, D., M. Oršanić, V. Paulić, 2015: Utjecaj AgroHidroGela i ektomikorize na preživljenje i početni rast sadnica hrasta lužnjaka (Quercus robur L.). Proizvodnja hrane i šumarstvo temelj razvoja istočne Hrvatske / Matić, Slavko ; Tomić, Franjo; Anić, Igor (ur.). - Zagreb: Hrvatska akademija znanosti i umjetnosti, 271.-294. str.

- Drvodelić, D., M. Oršanić, V. Paulić, 2016a: Utjecaj ektomikorize i huminskih kiselina na morfološke značajke jednogodišnjih sadnica hibrida Paulownia tomentosa $\times$ Paulownia fortunei. Šumarski list, 7-8: 327.-337.

- Drvodelić, D., D. Ugarković, M. Oršanić, V. Paulić, 2016b: The Impact of Drought, Normal Watering and Substrate Saturation on the Morphological and Physiological Condition of Container Seedlings of Narrow-Leaved Ash (Fraxinus angustifolia Vahl). South-east Eur for., 7 (2): 135.-142.

- Drvodelić, D., D. Ugarković, M. Oršanić, V. Paulić, 2016c: The Impact of Drought, Normal Watering and Substrate Saturation on the Morphological and Physiological Condition of Container Seedlings of Narrow-Leaved Ash (Fraxinus angustifolia Vahl). Seefor, 7 (2): 135.-142.

- Drvodelić, D., 2017: Ekologija i obnova poplavnih šuma Posavine, 2017: Znanstveno-istraživački projekt. Završno pisano trogodišnje izvješće pod projekta Uzgajanje šuma „Problematika sjemenarstva i rasadničke proizvodnje sadnica poljskog jasena (Fraxinus angustifolia Vahl.) i hrasta lužnjaka (Quercus robur L.)“, ur. Damir Drvodelić, Sveučilište u Zagrebu, Šumarski fakultet. U tisku. 75. str.

- Faulconer, J. R., 1988: Using frost hardiness as an indicator of seedling condition. In: Landis TD, technical coordinator. Proceedings, combined meeting of the western forest associations; 1988 August 9-11; Vernon, BC. Fort Collins (CO): USDA Forest Service, Rocky Mountain Forest and Range Experiment Station. General Technical Report RM-167: 89.-95. str.

- Glerum, C., 1984: Frost hardiness of coniferous seedlings: principles and applications. In: M. L. Duryea, editor. Evaluating seedling quality: principles, procedures, and predictive abilities of major tests. Proceedings of a workshop held October 16-18, 1984. Corvallis (OR): Oregon State University, Forest Research Laboratory:107.-123. str.

- Haase, D. L., R. W. Rose, J. Trobaugh, 2006: Field performance of three stock sizes of Douglas-fir container seedlings grown with slowrelease fertilizer in the nursery growing medium. New Forests, 31:1.-24.

- Haase, D. L., 2007: Morphological and Physiological Evaluations of Seedling Quality. USDA Forest Service Proceedings RMRSP-50: 3.-8. str.

- Harrington, J. T., J. D. Mexal, J. T. Fisher, 1994: Volume displacement method provides a quick and accurate way to quantify new root production. Tree Planters' Notes, 45:121.-124.
- Jelić, G., V. Topić, L. Butorac, Z. Đurđević, A. Jazbec, M. Oršanić, 2014: Utjecaj veličine kontejnera i pripreme tla na uspjeh pošumljavanja jednogodišnjim sadnicama bora pinije (Pinus pinea L.) na sredozemnom području Republike Hrvatske. Šumarski list, 9-10: 463-475.

- Jacobs, D. F., K. F. Salifu, J. R. Seifert, 2005: Relative contribution of initial root and shoot morphology in predicting field performance of hardwood seedlings. New Forests, 30:235.-251.

- Kozlowski, T. T., J. H. Torrie, P. E. Marshall, 1973: Predictability of shoot length from bud size in Pinus resinosa Ait. Canadian Journal of Forest Research, 3:34.-38.

- Landis, T. L., 1985: Mineral nutrition as an index of seedling quality. In: M. L. Duryea, editor. Evaluating seedling quality: principles, procedures, and predictive abilities of major tests. Proceedings of a workshop held October 16-18, 1984. Corvallis (OR): Oregon State University, Forest Research Laboratory: 29.-48. str.

- Lavender, D. L., 1985: Bud dormancy. In: M. L. Duryea, editor. Evaluating seedling quality: principles, procedures, and predictive abilities of major tests. Proceedings of a workshop held October 16-18, 1984. Corvallis (OR): Oregon State University, Forest Research Laboratory: 7.-15. str.

- Lopushinsky, W., 1990: Seedling moisture status. In: R. Rose, S. J. Campbell, T. D. Landis, editors. Target seedling symposium: combined proceedings of the western forest nursery associations; 1990 August 13-17; Roseburg, OR. Fort Collins (CO): USDA Forest Service, Rocky Mountain Forest and Range Experiment Station. General Technical Report RM-200: 123.-138. str.

- McKay, H. M., B. A. Gardiner, W. L. Mason, D. G. Nelson, M. K., 1993. The gravitational forces generated by dropping plants and the response of Sitka spruce seedlings to dropping. Canadian Journal of Forest Research, 23: 2443.-2451.

- McKay, H. M., 1997: A review of the effect of stresses between lifting and planting on nursery stock quality and performance. New Forests, 13(1-3): 369.-399.

- Mexal, J. G., Landis, T. D. 1990: Target seedling concepts: height and diameter. In: Rose, R., S. J. Campbell, T. D. Landis, editors. Target seedling symposium: combined proceedings of the western forest nursery associations; 1990 August 13-17; Roseburg, OR. Fort Collins (CO): USDA Forest Service, Rocky Mountain Forest and Range Experiment Station. General Technical Report RM-200: 17.-35. str.

- Omi, S. K., G. T. Howe, M. L. Duryea, 1986: First-year field performance of Douglas-fir seedlings in relation to nursery characteristics. In: Landis TD, editor. Proceedings, combined Western Forest Nursery Council and Intermountain Nursery Association meeting; 1986 Aug 12-15; Tumwater, WA. Fort Collins (CO): USDA Forest Service, Rocky Mountain Forest and Range Experiment Station USDA. General Technical Report RM 137:29. 34. str.

- Oršanić, M., D. Drvodelić, I. Kovačević, 2007: Rasadnička proizvodnja sadnica crnog oraha (Juglans nigra L.). Šumarski list 131, ( 5-6): 207.-217.

- Oršanić, M., D. Horvat, N. Pernar, M. Šušnjar, D. Bakšić, D. Drvodelić, 2008: Growth of Pedunculate Oak Seedlings under Soil Contamination by Mineral and Biodegradable Oils. Croatian journal of forest engineering, 29 (2): 155.-162.

- Oršanić, M., D. Horvat, N. Pernar, M. Šušnjar, D. Bakšić, D. Drvodelić, 2008: Utjecaj mineralnog i biorazgradivog ulja na rasadničku klijavost i rast sadnica hrasta lužnjaka (Quercus robur L.). Šumarski list, 131 (1-2): 3.-9.

- Oršanić, M., D. Drvodelić, D. Bobinec Mikek, V. Paulić, 2010: Utjecaj potencijala rasta korijena na preživljavanje i rast sadnica 
crnog bora (Pinus nigra Arnold). Glasnik za šumske pokuse, 43: 61.-72.

- Owens, J. N., M. Molder, 1973: A study of DNA and mitotic activity in the vegetative apex of Douglas-fir during the annual growth cycle. Canadian Journal of Botany, 51:1395.-1409.

- Paterson J. DeYoe D., S. Millson, R. Galloway, 2001: In: R. G. Wagner, S. J. Colombo, editors. Regenerating the Canadian forestprinciples and practice for Ontario. Markham (ON): Ontario Ministry of Natural Resources and Fitzhenry \& Whiteside Ltd:325.-341.

- Ritchie, G. A. 1984. Assessing seedling quality. In: Duryea ML, Landis TD, editors. Forest nursery manual: production of bareroot seedlings. Boston (MA): Martinus Nijhoff/Dr W Junk Publishers.243.-259. str.

- Ritchie, G. A., 1985: Root growth potential: principles, procedures and predictive ability. In: M. L. Duryea, editor. Evaluating seedling quality: principles, procedures, and predictive abilities of major tests. Proceedings of a workshop held October 1618,1984. Corvallis (OR): Oregon State University, Forest Research Laboratory: 93.-106. str.

- Roller, K. J., 1977: Suggested minimum standards for containerized seedlings in Nova Scotia. Fisheries and Environment Canada, Canadian Forestry Service, Maritimes Forest Research Centre. Information Report M-X-69: 18. str.

- Rose, R., D. L. Haase, F. Kroiher, T. Sabin, 1997: Root volume and growth of ponderosa pine and Douglas-fir seedlings: a summary of eight growing seasons. Western Journal of Applied Forestry, 12:69.-73.

- Rose, R., J. S. Ketchum, 2003: Interaction of initial seedling diameter, fertilization, and weed control on Douglas-fir growth over the first four years after planting. Annals of Forest Science, 60:625.-635.

- Sharpe, A. L., Mason, W. L, Howes, R. E. J. 1990: Early forest performance of roughly handled Sitka spruce and Douglas fir of different plant types. Scottish Forestry, 44: 257.-265.
- Simpson, D. G., 1990: Frost hardiness, root growth capacity, and field performance relationships in interior spruce, lodgepole pine, Douglas-fir, and western hemlock seedlings. Canadian Journal of Forest Research, 20:566.-572.

- Simpson, D. G., G. A. Ritchie, 1997: Does RGP predict field performance? A debate. New Forests, 13:253.-277.

- Smith, J. H., 1975: Big stock vs. small stock. In: Proceedings of the Western Forest Fire Committee; 1975 Dec 2-3; Vancouver, British Columbia. 107.-115. str.

- South, D. B., J. G. Mexal, J. P. van Buijtenen, 1988: The relationship between seedling diameter at planting and long term volume growth of loblolly pine seedlings in east Texas. IN: Proceedings of the 10th North American Forest Biology Workshop; 1988 July 20-22; Vancouver, British Columbia. 192.-199. str.

- Tabbush, P. M., 1986: Rough handling, soil temperature, and root development in outplanted Sitka spruce and Douglas-fir. Canadian Journal of Forest Research, 16: 1385.-1388.

- Tanaka, Y., P. Brotherton, S. Hostetter, D. Chapman, S. Dyce, J. Belanger, B. Johnson, S. Duke, 1997: The operational planting stock quality testing program at Weyerhaeuser. New Forests, 13423.-437.

- Thompson, B. E., 1985: Seedling morphological evaluation-what you can tell by looking. In: Duryea ML, editor. Evaluating seedling quality: principles, procedures, and predictive abilities of major tests. Proceedings of a workshop held October 16-18, 1984. Corvallis (OR): Oregon State University, Forest Research Laboratory:59.-71. str.

- Tsakaldimi, M., T. Zagas, T. Tsitsoni, P. Ganatsas, 2005: Root morphology, stem growth and field performance of seedlings of two Mediterranean evergreen oaks species raised in different container types. Plant Soil 278: 85-93.

- van den Driessche, R., 1980: Effects of nitrogen and phosphorus fertilization on Douglas-fir nursery growth and survival after outplanting. Canadian Journal of Forest Research, 10:65.-70.

\section{SUMMARY:}

This expert article describes in detail all the factors that affect the cultivation of quality forest seedlings of narrow-leaved ash for artificial regeneration and afforestation. So far no attention has been paid to the quality of the seedlings given the new and completely changed adverse ecological and biological factors occurring in narrow-leaved ash stands in Croatia. The quality of field ash seedlings was determined solely by one morphological factor, which is usually the shoot height, which is not good. The paper defines the concepts of morphological and physiological quality of seedlings. Methodologies for measuring the morphological and physiological characteristics of forest seedlings and their importance for survival, growth and growth after field planting are described. Morphological features include shoot height, stem diameter, height: diameter ratio, bud length, root and stem volume, weights, shoot: root ratio, and colour, form, and damage. Physiological properties are: cold hardiness, root growth potential (RGP), bud dormancy and foliar nutrient concentration. Three stress factors that affect the decrease in forest seedling quality, survival, growth, and field gains are described, namely: plant moisture stress (PMS), temperature stress, and physical stress (falling, crushing, vibration, surface damage, and root tearing).All other stress factors that affect the decline in the quality of forest seedlings, which occurs during the period from the nursery to field planting, have been identified. The role of an individual stress factor on seedlings is clarified, and so is the cumulative influence of multiple stress factors. The article deals with the correct handling of seedlings from harvesting in the nursery to afforestation. Recent patented protection options for seedlings from the time of removal from the nursery or cold storage truck to planting in the field are presented.

KEY WORDS: Morphological quality of forest seedlings, physiological quality of forest seedlings, stress factors in forest seedlings, seedling handling, seedling protection 